\title{
Ethnologies
}

\section{Intangible roles}

\section{Theory, policy, practice and intangible cultural heritage}

\section{Jo Littler}

Volume 36, numéro 1-2, 2014

Patrimoine culturel immatériel

Intangible Cultural Heritage

URI : https://id.erudit.org/iderudit/1037601ar

DOI : https://doi.org/10.7202/1037601ar

Aller au sommaire du numéro

\section{Éditeur(s)}

Association Canadienne d'Ethnologie et de Folklore

ISSN

1481-5974 (imprimé)

1708-0401 (numérique)

Découvrir la revue

Citer cet article

Littler, J. (2014). Intangible roles: Theory, policy, practice and intangible cultural heritage. Ethnologies, 36(1-2), 93-105. https://doi.org/10.7202/1037601ar

\section{Résumé de l'article}

L'intérêt pour le savoir non matériel et les formes de communication dans le domaine du patrimoine culturel immatériel peut être relié à la fois à l'intérêt grandissant des conservateurs de musée pour les expositions " expérientielles " et à la valorisation dans la société contemporaine de ce que l'on qualifie généralement « d'économie expérientielle ». Autrement dit, l'intérêt récent pour le patrimoine culturel immatériel pourrait tout à fait se replacer dans le contexte de ce que l'on a appelé le " virage culturel ». Ce contexte étant donné, l'auteur de cet article examine la façon dont le cas du patrimoine culturel immatériel met vivement en relief deux questions en particulier : premièrement, les controverses contemporaines cherchant à déterminer s'il est souhaitable que des universitaires s'attaquent à l'administration de la culture - à savoir si le fait d'entériner une politique représente une abdication des possibilités politiques - et deuxièmement, la question des limites de la politique culturelle, à savoir ce qu'il est possible d'administrer. Renonçant délibérément à une approche technocratique étroite, cet article soutient qu'il nous faut interroger l'héritage culturel du patrimoine culturel immatériel lui-même. Ce faisant, nous serons mieux outillés pour envisager à quoi pourraient ressembler les interactions imaginatives d'amples proportions entre la théorie, les politiques, les processus et les pratiques.
Ce document est protégé par la loi sur le droit d'auteur. L'utilisation des services d'Érudit (y compris la reproduction) est assujettie à sa politique d'utilisation que vous pouvez consulter en ligne.

https://apropos.erudit.org/fr/usagers/politique-dutilisation/ 


\section{INTANGIBLE ROLES}

Theory, policy, practice and intangible cultural heritage

\section{Jo Littler \\ City University London}

The case of intangible cultural heritage throws two particular issues into stark relief: first, questions about the boundaries of cultural policy, or what it is possible to administer; and second, heated contemporary debates over the desirability of academics engaging with the administration of culture. In this chapter I want to consider how we might perhaps be able to understand more about intangible cultural heritage, and what might be possible to do with it, by bringing it into contact with a number of debates in cultural studies, cultural policy and cultural theory.

In 2006, in an article in the international journal Cultural Studies, the British philosopher Peter Osborne critiqued the turn in cultural studies toward a greater engagement with cultural policy: with the new definition of culture as "a political-administrative resource." Osborne argues that in their search to "be relevant" and "have an effect", cultural theorists often do not critique the language of managerial administration that they are analysing, and in the process end up implicitly endorsing the neoliberalism that they should be critiquing. His point, in short, is that the

desire for a cultural studies linked to a transformative left populism [has] come to terminate in the sorry state of a cultural theory dedicated to legitimating an emergent political-administrative status quo (Osborne, 2006: 43).

Osborne argues that a more imaginatively useful route would be to pursue a greater engagement with the many strands of the philosophy of pragmatics, to uncover its richer traditions rather than simply practising a narrowly short-term expedient version of pragmatism, which, he suggests, would also involve a greater theoretical engagement with the politics of time. 
To some extent this piece deploys what Osborne describes earlier as "the clarifying power of the strategic use of exaggeration" (Osborne, 2006: 37). For as most academics thoroughly steeped in the field of cultural studies would recognise, there are clearly strands of cultural work in existence which do manage to engage with questions of policy whilst simultaneously interrogating the broader political context on which its analysis and recommendations are built (see McGuigan, 1996; 2004). In addition, it is also worth emphasising that some of the policy analyses Osborne is gesturing towards provide a set of critical terms to extend understandings of how policy works, which do not have to necessarily be articulated to neoliberal politics, or to a lack of interest in either the more complex genealogical meanings of pragmatism or the politics of time.

However, Osborne's critique interests me, partly as someone who has linked post-Marxist cultural studies with an analysis of cultural policy (Littler and Naidoo, 2004; 2005) and partly because to a large extent I think his analysis is both very useful and timely, in the most far-reaching and multiple senses of the terms. For it is the case that there can be a pronounced tendency in many governmentality-oriented studies in particular to analyse cultural policies and to suggest ways in which they could be improved whilst failing to interrogate the broader context and politics within which these policies are made in the first place. As Osborne, with customary clarity and incisive flair points out, this means they end up, despite themselves, endorsing the broader political agenda these policies are part of rather than critiquing it.

Given these factors, it seems worth considering how we might work with this argument as a means of helping us theorise perspectives beyond it; how we might use it as a prompt to investigate some of the deeper factors shaping the emergence of cultural forms - and, in this particular case, of the emergence of intangible cultural heritage. For if we apply the points I have extracted from Osborne's narrative to the case of intangible cultural heritage, the implication is that whilst analysing its strategic uses and policies as an instrument of governmentality, what we might do as well, at the same time, is to ensure that we capaciously interrogate, in a number of different ways, the heritage of intangible cultural heritage itself. In other words, what is termed "intangible cultural heritage" has clearly become an object of policy, but we might also think through what it might mean in its broader sense. Why has the term emerged in this particular contemporary conjuncture? What kinds of social, cultural and political contexts does the term borrow from and relate to? Here I want to consider these questions 
by situating intangible cultural heritage in particular theoretical contexts: first, in relation to that which is commonly termed in cultural studies and sociology as 'the cultural turn'; and second, in relation to the expansion in curatorial interest in 'experiential' displays and to the valorisation of what has, more broadly, been termed the 'experience economy' in contemporary society (Rojek, 1993; Pine and Gimour, 1999).

\section{Experiencing heritage}

Intangible cultural heritage, as Vladimir Hafstein has put it, has "a focus on practices and expressions that do not leave extensive material traces, at least not of monumental proportions" (Hafstein, 2005). The kind of practices it is associated with - such as storytelling, craftsmanship, rituals, dramas and festivals - do not simply involve looking at a particular material object. They are more experiential in nature. In addition, intangible cultural heritage marks a shift in emphasis in heritage policy from one of recording and 'capture' to an emphasis on the lived experiential moment itself; on facilitating embodied practice. This has involved an emphasis on both the wider field or system of practice and the practitioners involved. As Barbara Kirshenblatt-Gimblett puts it, over several decades

there has been an important shift in the concept of intangible heritage to include not only the masterpieces, but also the masters. [...] the most recent model seeks to sustain a living, if endangered, tradition by supporting the conditions necessary for cultural reproduction. This means according value to the 'carriers' and 'transmitters' of traditions, as well as to their habitus and habitat. (Kirshenblatt-Gimblett 2004: 53)

The emphasis in intangible heritage on sustaining a system as a living entity marks it as a phenomenon which combines elements of the adjacent categories of tangible heritage (in terms of sustaining tradition) and natural heritage (in terms of supporting a more 'holistic' system) (KirshenblattGimblett, 2004: 53). Such an emphasis on supporting practitioners and the conditions in which heritage is produced, rather than on recording such experience for posterity, is a significant shift in heritage policy toward a focus on the experiential environment. Or, as Hafstein puts it, "making sure that people keep singing their songs tomorrow is a task of a very different order from that of archiving the songs they sing today" (Hafstein, 2006: 1).

This more experiential nature of intangible cultural heritage can be related to a wider series of changes. In European and American heritage and museum cultures in particular, and especially over the past two decades, there 
has been an increasing amount of interest in the experiential dimension of heritage, in engaging with a broader range of sensory perceptions, in moving the frame of reference beyond solely emphasising the gaze toward a static object as enshrined in the form of the museum. This has been apparent, for example, in the presentation of exhibitions in museums as experiences, ones which emphasise the sensory nature of the event. In Britain, for example, we might cite Olafur Eliasson's The Weather Project at the Tate Modern, in which the large turbine hall section of the art gallery was turned into an ambient event replete with a large setting sun. Similarly, it is apparent in the ongoing rise of living history and heritage experience attractions (which have a long lineage through nineteenth century expositions and Scandinavian open air museums, but also expanded rapidly from the 1980s) and their rapid absorption as staple components of large traditional public museums (Pred, 1995; Lumley, 1988). It is apparent in curatorial discussion and debate which has self-consciously sought to expand the terms of reference beyond that of the visual and into a consideration of the other senses. In this respect, the emphasis on the experiential also ties in with what is characterised by Michael Bull and Paul Gilroy et al. in the journal The Senses and Society (launched in 2006) as a 'sensual revolution in the humanities, social sciences and the arts", a broader intellectual interest in the senses, in affect and the human sensorium, in its cultures, its politics and in what they term the "sociality of sensation" (Bull and Gilroy, 2006: 5).

These shifts towards valuing the senses and experiential cultures might be understood in a variety of ways. Perhaps their most obvious characteristic is how they seek to dislodge the post-Enlightenment prioritisation of the visual. Pasi Falk, for example, has outlined how some senses in Western culture have traditionally been accorded a more privileged status than others:

The link between sensory organisation and the [cultural and social] Order is also the basis on which senses are hierarchized into 'higher' and 'lower' ones. In the Western tradition, from Plato to Kant and after, the higher position is granted to the distant senses, especially the eye, while the contact senses are defined as the lower ones. (Falk, 1994: 10-11)

This distinction characterised the social space of the postEnlightenment Western museum, with its artefacts safely tucked away behind glass, its emphasis on visual consumption of static objects. As Doreen Massey has pointed out, vision has been privileged in Western culture precisely because it offers detachment (Massey, 1994: 223-224). The organisation of exhibitionary display in museums around visual culture 
means that the emphasis is mainly placed on distanced reflection. In so doing it has dominantly interpolated Cartesian individuals, targeting the observing mind and a mode of understanding that is implicitly framed as being purely or primarily cognitive in function.

The traditional hierarchies of worth which have been implicitly imbued in heritage display mechanisms can similarly be explored as political factors which have shaped our notions and organisation of understanding and experience. Heritage experience attractions and living history displays in Britain, for example, have like funfairs, been associated as 'lower' forms of display because traditionally vision has been privileged as higher, or more 'rarefied' than other senses (Bennett, 1995). The dissociation from such forms of sensory engagement was one mechanism through which the uppermiddle class museum consolidated its status as rarefied, as a 'cut above' and it was also, notoriously, a cultural means through which imperial superiority was coded (Bennett, 1995; 1998; Rojek, 1993).

Intangible cultural heritage, with its emphasis on multisensory knowing, on movement, sound, touch and smell, as well as vision, disturbs this traditional formulation. It can more readily appear to call for the engagement of bodies as well as minds in its use of sensory engagement, making it antithetical to a discourse of distanced spectatorship. It involves affective ways of understanding (Massumi, 1988; Howes, 2005), not simply the purely visual and cognitive. The sensory affects produced by these new forms of experiential heritage and display might therefore be understood, as, to some extent, and in this singular regard, subverting traditional, Western, individualised and distanced bourgeois aesthetics.

To some degree, consciousness of these factors - noticeably weighted toward issues of geography and ethnicity rather than class - marks policy actions in the field. Attempting to redress implicit and explicit Eurocentricism was a key driving factor shaping UNESCO's formation of intangible cultural heritage policies. By the 1990s, for instance, it had become increasingly apparent to UNESCO officials that their list of 'heritage masterpieces' was not representative of all corners of the globe:

For example, Europe's cultural heritage was over-represented in relation to the rest of the world; historic towns and religious buildings (cathedrals, etc.) were over-rep; the architecture was 'elitist' (castles, palaces etc.), and "in general terms all living cultures especially traditional ones with their depth, their wealth, their complexity and their diverse relationships figured very little on the list", noted the meeting of experts that met in June 1994 at UNESCO HQ. (Munjeri, 2004: 16) 
The emergence of intangible cultural heritage therefore marked a self-conscious shift away from a European model of heritage-as-pedigree and towards a Japanese and Korean model with its emphasis on 'Living Human Treasures' (Hafstein, 2004). The inclusion of intangible heritage as a legitimate category in some ways enabled these official categories of heritage to break beyond their Eurocentric moorings. For example, the advent of intangible cultural heritage might mean that alternative modes of spiritualism from those symbolically represented by a European church might be able to be validated. A shrine in Ise, Japan, continually reconstructed from scratch at various intervals over the past 1000 years - and which therefore bypasses discourses of materially authentic, 'tangible' heritage could now, in these terms, be recognised as potentially supportable. So too could the phenomenon of 'voodoo cultures' in Benin, which circumvent discourses of heritage as tied to a particular, authentic place, given that the location of voodoo temples have no spatial rules (Munjeri, 2004). The introduction of intangible cultural heritage as a category, then, with its emphasis on living systems and multisensory experience, has in part offered a means through which heritage policy could be instrumentally reconfigured to encompass forms of heritage beyond that of established Eurocentric conventions.

\section{Intangible cultural heritage and the cultural turn}

However, it would be foolish to assume that by virtue of the characteristic of multisensory engagement that all such phenomena become only carnivalesque liberations from the shackles of a repressive Western bourgeois norm. Rather, this is but one important discursive strand to take into consideration when attempting to understand the significance of intangible cultural heritage; one which, moreover, needs to both be understood in broader context and further picked apart. The awareness of the 'ocularcentrism' of Western bourgeois culture also needs to be understood as part of the broader context of the 'cultural turn' since the 1970s. The downsizing and piecemeal outsourcing of the heavy Fordist-style manufacturing industry in the West has been accompanied by the expansion of the service economy and the cultural and creative industries; by time and money being poured into the niche marketing and branding of cultural products and experiences. Cultural capitalism has relied on what Maurizio Lazzarato, Michael Hardt and Antonio Negri term "immaterial labour": on creative work becoming practised in rich metropolitan zones of 'the first world' whilst old-fashioned industrial manufacturing either happens a few 
miles away in what Manuel Castells calls "fourth worlds" (downsized zones of social exclusion) or is outsourced overseas to economically impoverished countries (Lazzarato, 1996; Hardt and Negri, 2005: 65; Castells, 1998: 164 165). This context, as these and other social theorists have argued, has been facilitated by the 'rolling back' of state collective provision, by the dismantling of regulations that sought to protect people and areas of life against the worst excesses of capitalism and by the incremental granting of more power to corporations characteristic of neoliberal culture.

The 'cultural turn' is, first of all, then, a phrase used to register this shift toward change in production and consumption in the post-Fordist network society and to the expansion of 'creative' or 'cultural' labour. It is important to point out that this term is also used to indicate the turn towards cultural analysis in the humanities and social sciences since the 1970s as well as to the relationship between these two meanings (Hall, 1997: 207-238). Taken together, they indicate the turn toward a greater and more explicit emphasis on cultural experience: what Stuart Hall calls "the centrality of culture" or the "cultural revolution of our time".

Looking at this broader landscape, we can see how the emphasis on multiple sensory dimensions and the centrality of cultural experience might and has been connected or articulated to a range of different contexts and involves a wide range of power dynamics. For example, emphasising the experiential nature of culture and sensory experience has become integral to a great deal of corporate business practice. As Timothy D. Malefyt puts it, "in the world of marketing, facts and objectivity are out, while sensations and emotions are in" (Malefyt, 2006: 132). The bible of this form of corporate practice is Pine and Gilmour's book The Experience Economy, which proclaims that "work is theatre... and every business is a stage". As they put it, "those businesses that relegate themselves to the diminishing world of goods and services will be rendered irrelevant. To avoid this fate, you must learn to stage a rich, compelling experience" (Pine and Gilmour, 1999: 25).

My point here, then, is to highlight that intangible cultural heritage might be thought of as coming into being as a term because of the centrality of culture and the notion of experience in post-Fordist late modernity, with all the positive and negative connotations this brings. Therefore, whilst its use might subvert western bourgeois norms, intangible cultural heritage is not de facto politically neutral. Theoretically, it can be used to extend forms of social inequality as well as to reject it; it is open to being articulated in a number of ways. 


\section{Questioning forms of engagement}

Whilst intangible cultural heritage is clearly on one level an attempt to redress cultural marginalisation, the broader context and the range of possible articulations made by experiential cultures therefore means that it is also important to question what power dynamics are involved - even to ask whether it might perpetuate forms of ethnocentrism, despite its clear aim to globally broaden established criteria of heritage. In other words, what this points towards is the need to ensure that we investigate how the complicated business of the past-in-the-present is working in this context in all its complexity. As Bill Schwarz has argued, thinking about how the past actually relates to present day issues in heritage remains the least developed aspect of post-colonial research, an issue which also relates us back to Osborne's point about the necessity to address the politics of time. The work of sociologist Barnor Hesse holds one good template for addressing this issue through what he terms "an ethics of post-colonial memory". Analysing the presentation of America's slave heritage in Stephen Spielberg's film Amistad, Hesse argues that an "ethics of postcolonial memory" should involve remembering and re-excavating "the numerous interdependencies that obtained between Christianity and slavery, liberalism and imperialism, democracy and racism [... and how] the slavery plantation complex's formative relations of exploitation, exoticism, racism, and violence produced the consumerist contours of Western culture" (Hesse, 2002: 160). In short, what it means to "remember" now, Hesse argues, does of course involve "refusing to efface through forgetfulness" the implications of colonialism and slavery, but it simultaneously means acting against their contemporary legacies (Hesse, 2002: 165). Without this activity, we simply tuck such injustices safely into the past, fetishising them as self-contained and hermetically sealed from the present. What we might term, following Hesse, an "ethics of postcolonial heritage" (Littler and Naidoo, 2005), therefore, would involve not just remembering how slavery and oppression existed in the past, but re-excavating its complicated links to the contemporary neo-imperial day. In the case of intangible cultural heritage, this means being open to examining how intangible cultural heritage engages productively with the cultural inequalities of the present.

Now, clearly, as we have seen, in several key ways intangible cultural heritage does very precisely seek to engage with the present. It has been explicitly concerned with emphasising sustainable conditions in the present moment by supporting systems that can maintain heritage decreed as being valuable. However, at the same time, there are some problematic 
ways in which it engages with issues of contemporary inequalities and dynamics of power. First, its engagement with non-Western marginalised forms of heritage can arguably tend to smuggle ethnocentric criteria through the back door rather than genuinely expanding the heritage field and divesting it more thoroughly from perpetuating such hierarchies. As Barbara Kirshenblatt-Gimblett has outlined, forms of heritage favoured by UNESCO under the rubric of intangible cultural heritage "preserves the division between the West and the rest". Favouring non-Western heritage, intangible cultural heritage, she writes, produces an implicit "phantom list" of absent Western forms. Kirshenblatt-Gimblett points out that the consequence of this practice is an inconsistency between intangible cultural heritage's aims and effects: whilst Japan, for instance, is already well represented on world heritage programmes, Japanese culture becomes additionally favoured simply by virtue of being non-European. Such criteria necessarily situate "intangible cultural heritage within an implicit cultural hierarchy", although this hierarchical criterion is not articulated as such (Kirshenblatt-Gimblett, 2004).

In these terms, even when intangible cultural heritage is intended to be a means to extend the reach of officially supportable global heritage, the way it is used can work to reinforce ethnocentric categories. This issue clearly relates to a wider set of questions about how cultural policies are used to negotiate and engage with questions of 'race'. In particular, it raises the spectre of whether there is a kind of 'plaster effect' at work here: one in which cultural policy initiatives - however good they are - might be being accorded the task of having to do 'too much work', of being made responsible for papering over the cracks of social inequality. This is a charge that was in the recent, pre-crisis past levelled at British cultural policies concerned with heritage (Martin, 2005), as cultural policy in Britain was increasingly given the hard and lonely task of combating cultural and social exclusion at the same time as the New Labour government pursued an agenda carved out by Thatcherism, by eroding the public sector and giving corporate businesses a far greater role in running schools, hospitals and public services. Such political moves directly contradicted the impulses gestured towards in cultural policy. Cultural policy can therefore become a space to which questions of exclusion and marginalisation can be paid a conspicuous form of 'lip service' without significant engagement being mirrored in adjacent forms of social and political policy and practice.

This issue relates back to Osborne's analysis of the use of culture as a "politico-administrative resource" with a capacity to legitimise the status 
quo. Whilst cultural policy is not always used in this way, we can recognise that there is a need to be vigilant and critical when it does; to analyse when cultural policies on heritage are being used to safeguard vested power dynamics and perpetuate rather than redress forms of inequality. In other words, whilst intangible cultural heritage might be seen to 'give' on the one hand (in terms of broadening global reach of 'official' forms of heritage) elements of its current rationale and mode of organisation can mean that it also 'take away' on the other (by implicitly reinforcing modes of heritage as 'other', or completely bypassing its connection to contemporary power relations).

The dangers of the 'plaster effect' can be seen in more detail if we might question the role of agency and conflict around intangible cultural heritage. As Richard Kurin points out, UNESCO policies identify intangible cultural heritage as entities which meet very strict ethical criteria:
to be recognised, ICH has to be consistent with human rights, exhibit the need for mutual respect between communities, and be sustainable. This is a very high and one might say unrealistic and imposing standard. [The UNESCO conventions]... see culture as generally hopeful and positive, born not of historical struggle and conflict but of a varied flowering of diverse cultural ways. (Kurin, 2004: 70)

As Kurin puts it, the implicit model of culture in use is one that bypasses issues of struggle in favour of asserting 'good' examples of heritage. In a sense, then, intangible cultural heritage might be seen as being at a stage similar to earlier debates around 'multiculturalism'. The criterion Kurin identifies has parallels to the use of 'positive role models' for black communities which were roundly critiqued for failing to recognise, account for and therefore tackle the reasons why such role models were needed in the first place (Naidoo, 2005). In other words, whilst it would clearly be nice if all heritage were nice, or if all heritage practices automatically met a high ethical criteria, they clearly don't; and ignoring this factor runs the risk of glossing over very real and very important differentials of cultural power both past and present. This point correlates with Barbara KirshenblattGimblett's argument that intangible cultural heritage protocols can tend to speak of performers as "bearers" or carriers of tradition: as passive vessels rather than active, reflective subjects. As Chantal Mouffe has argued, systems that attempt to erase the issues of conflict and struggle only lead to totalitarianism (Mouffe, 2005) and to avoid this it is necessary to foster an agonistic space where power differentials can be seen if we are ever to hope to deal with them. The problem with erasing issues of power is that, 
instead of opening up its capacities to connect to what Hesse termed as "an ethics of postcolonial memory", intangible cultural heritage instead opens up its capacity to connect to the smooth spaces of the neoliberal experience economy. This is the logical consequence of the 'plaster effect'.

To consider issues of heritage in their broader context is one way of attempting to make sure that we do not merely blindly follow the parameters of policy, and that we will be better equipped to consider what capacious, imaginative interactions between theory, policy, process and practice might look like. Whilst intangible cultural heritage breaks new ground in extending heritage policy beyond a Eurocentric model, its current formations risk disengaging from the questions of power they seek to address. Without recognising the uneven surfaces of power from which heritage comes, without arecognition that heritage changes through its practitioners, such policies run the risk of becoming over-congruent with commodified experience. Despite these problems, intangible cultural heritage has some very good propensities for engaging with inequalities of power. Hardwired into its very terminology is a sense of the importance of transmission, of heritage as something living, transversal and in use. This quality - its ingrained sense of cultural transmission and collaboration may turn out to be the most important part of the legacy of the moment of intangible cultural heritage, as long as ways can be found to orient it away from a narrow form of pragmatic implementation. 


\section{References}

Bennett, Tony, 1995, The Birth of the Museum: History, Theory, Politics. London and New York: Routledge.

Bennett, Tony, 1998, Culture: A Reformer's Science. London and New York: Sage.

Bull, Michael, Paul Gilroy, David Howes and Douglas Kahn, 2006, "Introducing Sensory Studies." Senses and Society 1(1): 5-7.

Castells, Manuel, 1998, End of the Millennium. Oxford and New York: Blackwell.

Falk, Pasi, 1994, The Consuming Body. London and New York: Sage.

Hafstein, Valdimar, 2004, The Making of Intangible Cultural Heritage:

Tradition and Authenticity, Community and Humanity. PhD Dissertation, Berkeley: University of California.

Hafstein, Valdimar, 2005, "The Making of Intangible Cultural Heritage: Tradition and Authenticity, Community and Humanity." In UNESCO 2005 Symposium proceedings. http://portal.unesco.org/en/ev.php-URL_

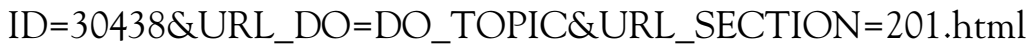

Hafstein, Vladimir, 2006, 'Community as Intangible Cultural Heritage: Government in the Vernacular'. Paper presented at 'The Politics of Intangible Cultural Heritage' Conference, Weatherhead Center for International Affairs, Harvard University, May 4-6.

Hall, Stuart, 1997, "The Centrality of Culture." In Kenneth Thompson (ed.), Media and Cultural Regulation: 207-238. London and New York: Sage.

Hardt, Michael and Antonio Negri, 2005, Multitude: War and Democracy in the Age of Empire. London: Penguin.

Howes, David (ed.), 2005, Empire of the Senses: The Sensual Culture Reader. Oxford: Berg.

Kirkinen, Heikki (ed.), 1999, Protection and Development of Our Intangible Heritage. Joensuu: Joensuu University Faculty of Humanities.

Kirshenblatt-Gimblett, Barbara, 2004, "Intangible Heritage as Metacultural Production." Museum International 56(1-2): 52-65.

Kurin, Richard, 2004, "Safeguarding Intangible Cultural Heritage in the 2003 UNESCO Convention: A Critical Appraisal." Museum International 56(1-2): 66-77.

Littler, Jo and Roshi Naidoo, 2004, "White past, multicultural present: heritage and national stories." In Robert Philips and Helen Brocklehurst (eds.), History, Identity and the Question of Britain: 330-341. Basingstoke: Palgrave.

Littler, Jo and Roshi Naidoo (eds.), 2005, The Politics of Heritage: The 
Legacies of 'Race'. London and New York: Routledge.

Lazzarato, Maurizio, 1996, "Immaterial Labour." In Michael Hardt and

Paolo Virno (eds.), Radical Thought in Italy: A Potential Politics: 133-147.

Minneapolis: University of Minnesota Press.

Lumley, Robert (ed.), 1988, The Museum Time-Machine. London: Routledge. Malefyt, Timothy D., 2006, "Surface or Depth? Reviewing Two Approaches to Consumer Experience in Marketing." Senses and Society 1(1): 129 132

Massey, Doreen, 1994, Space, Place and Gender. Cambridge: Polity Press. Martin, Steve, 2005, "Inheriting Diversity: Archiving the Past." In Jo Littler and Roshi Naidoo (eds.), The Politics of Heritage: The Legacies of 'Race': 196-201. London and New York: Routledge.

Massumi, Brian, 1988, “Translator's preface.” In Gilles Deleuze and Félix Guitarri, A Thousand Plateaus: Capitalism and Schizophrenia: ix-xv. London: Athlone Press.

McGuigan, Jim, 2004, Rethinking Cultural Policy. Maidenhead: Open University Press.

McGuigan, Jim, 1996, Culture and the Public Sphere. London and New York: Routledge.

Mouffe, Chantal, 2005, On The Political. London and New York: Routledge. Munjeri, Dawson, 2004, "Tangible and Intangible Heritage: From Difference to Convergence." Museum International 56(1-2): 12-20.

Naidoo, Roshi, 2005, "Never Mind the Buzzwords: 'Race', Heritage and the Liberal Agenda." In Jo Littler and Roshi Naidoo (eds), The Politics of Heritage: The Legacies of 'Race': 36-48. London and New York: Routledge.

Osborne, Peter, 2006, "Whoever speaks of culture speaks of administration as well." Cultural Studies 20(1): 33-47

Pine, B. Joseph Pine II and James H. Gilmour, 1999, The Experience Economy. Cambridge: Harvard University Press.

Pred, Alan, 1995, Recognising European Modernities: A Montage of the Present. London and New York: Routledge.

Rojek, Chris, 1993, Ways of Escape: Modern Transformations in Leisure and Travel. Cambridge: Macmillan.

Slater, Don and Fran Tonkiss, 2001, Market Society. London and New York: Sage.

Unesco, 2005, Report of the Expert Meeting on Inventorying Intangible Cultural Heritage, 17-18 March, Paris. Paris: Unesco.

Yudice, George, 2003, The Expediency of Culture: Uses of Culture in the Global Era. Durham: Duke University Press. 